\title{
Review
}

\section{The monarchy of fear: A philosopher looks at our political crisis}

\author{
Martha C. Nussbaum \\ Simon \& Schuster, New York, 2018, ix + 249pp., \\ ISBN: 978-1501172496
}

Contemporary Political Theory (2020) 19, S149-S152. https://doi.org/10.1057/s41296018-00305-9; published online 2 January 2019

In The Monarchy of Fear, Martha C. Nussbaum offers a compelling diagnosis of the emotional terrain of American political life in the era of Donald Trump. According to Nussbaum, fear - which she theorizes at length in chapter 2 currently undermines citizens' capacities for constructive deliberation across the partisan divide. Probing how fear mingles with the emotions of anger, disgust, and envy (chapters 3-5), Nussbaum examines how this toxic mixture has amplified political forms of misogyny (chapter 6), and reflects on how citizens can resist fear and all its troubling manifestations by embracing hope (chapter 7).

Written for a general audience, Monarchy of Fear is also of interest to philosophers and political theorists of emotions. Those interested in the politics of fear, in particular, will find much of value in the excellent second chapter. Here, Nussbaum builds on Aristotle's definition of fear in the Rhetoric (2009, 2.5), which she describes as 'pain at the seeming presence of some impending bad thing, combined with a feeling that you are powerless to ward it off' (2009, p. 24). Drawing also from psychoanalyst D. W. Winnicott, Nussbaum grounds her account of fear in the experience of infantile helplessness, which she describes as 'the stuff of nightmares', that expresses the 'completely, simply, helpless' condition of a newborn, whose 'rapid cognitive development' outstrips its capacity for physical self-sufficiency (pp. 17-19). While acknowledging how emotions are 'shaped in countless ways by social contexts and social norms' (p. 12), Nussbaum argues that fear always 'persists beneath the fabric of daily life', for both good and ill (p. 43).

Central to Nussbaum's account of the negative effects of fear is the figure of the absolute monarch, whom she positions as an analogue to the helpless infant. Citing Jean-Jacques Rousseau's Emile, Nussbaum explains how absolute monarchs are like infants insofar as they 'have no way of surviving except by making slaves of others', and thus must either 'rule or die' (p. 22). The infant-like monarch does double work for Nussbaum. Primarily, this figure serves to illustrate the irrational experience of fear, and how a feeling of powerlessness can lead people to 'grasp for

(C) 2019 Springer Nature Limited. 1470-8914 Contemporary Political Theory Vol. 19, S2, S149-S152 
control' in a way that promotes narcissism and scapegoating (p. 8). Nussbaum also analogizes the 'imperious baby', who forces 'others to do his bidding' by, for example, feigning cries of hunger (p. 31), to a demagogue, who uses fearmongering rhetoric to stir up concerns over potential political enemies, and who thus turns the irrational fears of others to his personal advantage.

Nussbaum finds an example for this kind of demagoguery in the 'fiery populist' Cleon from Thucydides' The War of the Peloponnesians and the Athenians (2013), who, while not fearful himself, provokes the Athenians to grasp fearfully for control when he urges them to murder and enslave the citizens of their rebellious tributary state, Mytilene (p. 45). Claiming that Cleon's efforts to 'other' potential allies 'should strike us as familiar' (p. 46), Nussbaum treats as evidence of the narcissistic, exclusionary, and ultimately anti-deliberative effects of such monarchical fear recent increases in Islamophobia and Trump's 2017 'clash of civilizations'-style speech in Warsaw. According to Nussbaum, Trump's appeals, much like those of Cleon, aim to provoke an 'amorphous fear' among their audiences, one 'generated in a climate of ignorance and fed by imprecise and alarmist rhetoric' (p. 60). Instead of urging deliberation about potential solutions to actually endemic sources of violence, such as gun deaths, Trump's speeches, she maintains, distort the nature of the threats facing American citizens. Notably, despite her reference to the 'imperious baby', and her figurative use of the monarch as an exemplar for the experience of fear, Nussbaum does not consider how those in actual positions of power might fear-monger out of their own sense of fear. Her analysis of fear's dangers in this chapter remains pitched in the register of the ruled.

Nussbaum's treatment of fear's irrationality is illuminating. At the same time, there is an important difference between the kind of fear experienced by infants and monarchs: unlike infants, monarchs are not powerless. In fact, to the extent that monarchs experience fear, this may be precisely because they are powerful. They have a vested interest in maintaining their power, and thus fear losing it. At least, this is how Nussbaum's ancient Greek interlocutors, Aristotle and Thucydides, understand absolute monarchy, which they treat as tantamount to tyranny. Illustrating the kind of fear experienced by rulers, a dynamic about which Nussbaum has less to say, are their treatments of the fear felt by tyrants. Aristotle maintains, in the Rhetoric and Politics (2013), for example, that in tyrants, who are always oriented to protecting their power (Rhet. 1366a; Pol. 1314a37), fear is not anti-deliberative but rather motivates deliberation (Rhet. 1383a; Pol. 1314a15-26): about how to undermine their subjects' capacities to trust one another, their subjects' desire for self-rule, and thus their willingness to act collectively against tyranny. Aristotle also illuminates the practical interdependence of the ruler's fear and that of the ruled, showing how the fearful tyrant promotes a similarly rational fear among his subjects, who deliberate, however, not about protecting their power, but about their well-being and that of their loved ones (Pol. 1313b16; Nicomachean Ethics 2012, 3.1). 
The rational kind of fear experienced by rulers with power is also on display in Thucydides' account of the Mytilenian debate. Indeed, it plays a central role in Cleon's appeals to the citizens of imperial Athens, whom he exhorts to make an example Mytilene to safeguard the power of their empire, which he identifies as a tyranny for their subject cities (III.37.2). Irreducible to populist demagoguery, Cleon's appeals also represent a realist's strategic reaffirmation of the (lessdemagogic) Periclean claim - made earlier in the war - that Athens is 'like a tyranny:' its power may be wrong to take, but is nevertheless too 'perilous to abandon' (II.63.2).

Noticing how fear informs rational, interest-driven anxieties brings more clearly to light nuances already implicit in Nussbaum's especially strong chapter 6, which considers how misogyny, defined as 'a determined enforcement of gender privilege', may have secured Trump's popularity among white male voters, anxious about defending their economic and social privilege (p. 177). As Nussbaum aptly puts it, misogyny's 'primary root is in self-interest, combined with anxiety about potential loss' (p. 177). Considering America's history of patriarchal exclusion, Nussbaum notes that misogyny 'is not symmetrical to female hatred of men' (p. 177). Since women lack the kind of 'entrenched interests' (p. 180) of misogynists bent on protecting their power, misandry, 'to the extent that this exists', would be closer to a sense of grievance or a desire for retribution (p. 177). Nussbaum's account draws attention to how misogyny emerges from a context in which men, who possess disproportionate political and economic power, strive to defend that power out of a fear of losing it. In this way, they are not unlike the tyrants and tyrannical cities described by Aristotle and Thucydides.

In the final chapter, Nussbaum considers how hope might counter the fear-driven desire for absolute power. Here she draws on Adrienne Martin, Immanuel Kant, Martin Luther King, Jr., and Nelson Mandela to underscore how hope can inspire constructive action, and how, by keeping faith in the capacities of others to do good - especially those with whom we disagree - those others might 'try to live up to that expectation' (p. 218). Nussbaum concludes by considering a series of potential 'schools of hope', including the arts, critical dialogue, religion, protest movements, theories of justice, and a national service program. Demonstrating a robust appreciation for how entrenched economic inequalities might hinder an education in hope, Nussbaum returns to her capabilities approach as a theory of justice that seeks to ensure hope's material preconditions.

While Nussbaum's closing account of these schools of hope is arresting, it left me hoping for more examples from the present day, especially in the section on protest movements. Here, Nussbaum alludes to King and the Civil Rights Movement and briefly mentions the Movement for Black Lives, which seems like it would be an especially productive case for Nussbaum to engage with in greater depth. For example, in her discussion of justice, Nussbaum could have drawn on the commitment to economic justice contained in the Movement's platform (2015).

(c) 2019 Springer Nature Limited. 1470-8914 Contemporary Political Theory Vol. 19, S2, S149-S152 S151 
Similarly, as examples of policies that are in line with her capabilities approach, she could have highlighted the Movement's demand for the reallocation of federal funding away from policing and incarceration and towards employment and universal health care.

Nussbaum claims that 'we often think better, and relate to one another better, when we take a step back from the daily, where our immediate fears and wishes are likely to be at stake' (p. 16). Her account of fear demonstrates the value of maintaining such a distance. At other points, particularly in Nussbaum's discussion of misogyny, The Monarchy of Fear also demonstrates that insightful analysis can be accomplished by doing otherwise. Consistently lucid and insightful, Nussbaum's book offers a generative perspective from which to assess our social and political moment.

\section{References}

Aristotle. (2009). Rhetoric in Gorgias and Rhetoric. (J. Sachs, Trans.). Newburyport: Focus.

Aristotle. (2012). Nicomachean Ethics. (R. C. Bartlett \& S. D. Collins, Trans.). Chicago: University of Chicago Press.

Aristotle. (2013). Politics (2nd ed.). (C. Lord, Trans.). Chicago: University of Chicago Press.

Movement for Black Lives. (2015). A Vision for Black Lives: Policy Demands for Black Power, Freedom and Justice. Retrieved from https://policy.m4bl.org/platform/.

Thucydides. (2013). The War of the Peloponnesians and the Athenians. (J. Mynott, Trans.). London: Cambridge University Press.

Publisher's Note Springer Nature remains neutral with regard to jurisdictional claims in published maps and institutional affiliations.

Jordan Jochim Cornell University, Ithaca, NY 14850, USA jdj74@ cornell.edu 